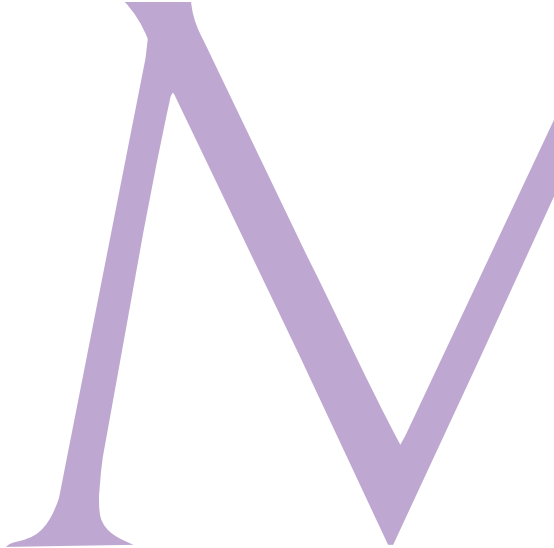

CiênCia Aberta

\section{Processos abertos na prática científica}

Mais do que compartilhar. Ter acesso livre, aberto e, portanto público e participação colaborativa aberta. Essa é a base do movimento Open Science ou Ciência Aberta, um modo de fazer pesquisa que vem ganhando adeptos em várias partes do mundo, inclusive no Brasil. $\mathrm{O}$ movimento, que surgiu oficialmente em 2009, defende que as pessoas devem ser livres para usar, reutilizar e distribuir o conhecimento científico, sem restrições legais, tecnológicas ou social. Ele incorpora noções do Open Source, que começou no fim do século XX e que lida com a abertura dos códigos dos programas de computador, e do Open Access, que visa o livre acesso a publicaçóes e a construção colaborativa do conhecimento. Como um grupo de trabalho, o Open Science promove eventos e coordena discussões em todo mundo sobre a ciência aberta e ainda desenvolve ferramentas para cientistas e editores para ajudá-los a compartilhar dados. Ele é uma das linhas de atuação da Open Knowledge Foundation, instituição criada em 2004, no Reino Unido e que promove o conhecimento aberto na era digital.
"A ciência se faz colaborativamente. Mas, para que a colaboração possa de fato ocorrer, a condição essencial é que a informação flua livremente. Para o conhecimento poder evoluir ele precisa circular. $\mathrm{O}$ pesquisador deve ter o mais amplo acesso aos trabalhos de outros pesquisadores para, assim, gerar avanços para todos. É o conhecimento que gera mais conhecimento, que pode resultar em inovação", analisa Beatriz Cintra Martins, pesquisadora do grupo de pesquisa Novas Tecnologias, Cultura e Práticas Interativas e Inovação em Saúde, na Fundação Oswaldo Cruz (Fiocruz).

COLABORAÇõES Beatriz acrescenta que a ideia do compartilhamento é ampliada no Open Science. "São iniciativas de pesquisa colaborativa, nas quais as diversas etapas vão sendo divulgadas, sem a preocupação com o registro de patentes ou com a prévia publicação de artigos, o que é padrão na pesquisa tradicional", aponta a pesquisadora. Um exemplo é o consórcio Open Source Drug Discovery (OSDD), lançado em 2008, com financiamento do governo indiano. "Baseada nos princípios 'colaborar, descobrir e compartilhar', a iniciativa tem como objetivo produzir medicamentos acessíveis às populações dos países em desenvolvimento". Pelos dados do site, são mais de 7,5 mil participantes de 130 países.
Para Alexandre Hannud Abdo, cientista molecular e pesquisador da Faculdade de Medicina da Universidade de São Paulo (USP), uma Ciência Aberta é a essência da própria ciência. "Se considerarmos os valores filosóficos e bases epistemológicas, podemos afirmar que, se não é aberto, não é ciência”. Ele ressalta que essa abertura tem relação direta com as tecnologias disponíveis e conclui que o movimento Ciência Aberta pode ser entendido como um processo de atualização das práticas científicas frente a essas novas tecnologias. No caso, a internet.

Aliada a essa incorporação, o movimento também é uma reação às restrições impostas quanto à prática e aplicação do conhecimento científico, que na opinião de Abdo, servem para garantir interesses particulares. "Há grupos da sociedade civil cobrando que o produto de investimentos públicos em ciência seja disponibilizado em domínio público. Essa pressão é fundamental. Não faz sentido ter um movimento de Ciência Aberta que não inclua cidadãos interessados na ciência. E esse comprometimento público é parte da motivação dos cientistas profissionais que participam do movimento", avalia.

Abdo participa do grupo de trabalho em Ciência Aberta, criado com o objetivo promover discussões pa- 
